\title{
Exploring the use of MXit - a cellphone social network to facilitate learning in distance education
}

\author{
Dr Mpine Makoe \\ Institute for Open Distance Learning, \\ University of South Africa, \\ PO Box 392, \\ UNISA, 0003, \\ South Africa, \\ tel. +27 12 429-6603, fax: +27 12 429-3630, \\ e-mail qakisme@unisa.ac.za
}

\begin{abstract}
The aim of this paper is to investigate the pedagogical suitability of using cellphones to enhance learning through social interaction in distance education. Social interaction was used as a conceptual framework to explore the potential for using "MXit" - a cellphone instant messaging system - to support and enhance learning for distance education students. In exploring how MXit could be used to facilitate social interaction, a pilot study was conducted with University of South Africa's (UNISA) students to determine how communities of learning are established. The findings suggest that MXit has the potential to be used to support collaborative learning amongst distance learners. Using MXit is even more appropriate in this context because in most black South African cultures, collaborative learning is a strong factor determining values and social interaction.
\end{abstract}

Keywords: Cellphones, social network, distance education, collaborative learning, MXit, University of South Africa 


\title{
Exploring the use of MXit - a cellphone social network - to facilitate learning in distance education
}

\author{
Dr Mpine Makoe \\ Institute for Open Distance Learning, \\ University of South Africa, PO Box 392, \\ UNISA, 0003, South Africa, \\ tel. +27 12 429-6603, fax: +27 12 429-3630, \\ e-mail qakisme@unisa.ac.za
}

\section{CONTEXT}

The effects of mobile technologies on the way we communicate, the way we write and the way we relate to each other can never be underestimated. The multimedia functionality and its simpler and user-friendly interface make cellphones easier to use by people who may be uncomfortable with using other technologies such as computers. The lack of electricity, computers, and telephone networks; and the poor roads and postal services in most developing countries have led to a rapid growth of wireless technology. Subscribers of cellphone users in South Africa were 45 million out of the population of 48 million in 2008 , according to the 2010 World Factbook. Cellphones are the only means of communication for most people who live in remote rural areas. Therefore, the use of cellphones is better suited in distance education because they increase the possibility of learning that is not tied to a physical location. Their portability enables students to learn anywhere, everywhere and anytime.

One of the biggest challenges facing the University of South Africa (UNISA), as a distance education institution, is to provide support and education for students who are geographically isolated from their teachers as sources of information and separated from their peers as sources of support. The effects of such isolation are even more acute in places of limited resources such as rural South Africa. UNISA students reported that they need support mechanisms that would enhance social interaction (Makoe, 2007). Cellphones hold such a promise for distance education as a cognitive delivery tool to enhance collaborative learning and social interaction because more than 98 percent of UNISA students have access to or own a cellphone and most of those cellphones have software features such as camera, video, music, games, instant messaging and the internet (UNISA, 2009). Even the low-end 
cellphones have some of these features, enabling them to be used in education for collaboration, tutoring, research, reading and writing purposes (Prensky, 2001).

The mediating role of mobile technology to support active and collaborative learning is based on Vygotsky's (1930/1978) socio-cultural perspective where he argues that students' development is determined by social interaction through problem-solving under the guidance of a teacher or in collaboration with capable peers. Vygotsky argues that social interactions are methodologies that turn experience into knowledge, with language as a medium for negotiation of teaching and learning. Therefore, social interaction will be used as a conceptual framework to explore the potential for using "MXit" - a cellphone instant messaging software application developed in Stellenbosch, South Africa. It runs on GPRS/3G cellphones with java support and is freely downloadable onto cellphones and personal computers. Even some low-end cellphones use GPRS for text or picture messaging, therefore most people who own GPRS-enabled cellphones have access to it.

As a network-independent platform, MXit does not charge for sending and receiving text messages but some cellphone operators do charge a minimal cost of 2 cents per text message; SMS text messages cost at least 50 cents depending on the service provider. In South Africa all cellphone operators offer data traffic at a far lesser price than SMS traffic (Butgereit, 2007). The low cost factor of MXit makes it very attractive to young people. It has a registered user base of over 15 million people all over the world and the great majority of them are in South Africa. It has about 20 million log-ons per day and over 250 million messages sent/received per day. The number of MXit users is greater than the total number of landlines installed in the entire country. More than 80 percent of its users are between the ages of 12 and 25 (MXit, 2010). This software provides a platform where people can meet, share and develop knowledge and understanding of their own social world.

The use of MXit is uniquely situated to support distance education students because they are already familiar with it. The idea is to build on an informal learning social context that most students are familiar with to develop formal learning opportunities and support mechanisms for distance education students, even those who live in remote rural areas. The aim of the study is to investigate the pedagogical suitability of using cellphones, particularly social networks, to enhance learning through social interaction. The ubiquitous nature of mobile learning promotes active and collaborative learning that often leads to critical thinking, communication skills and the building of social relationships. 


\section{SOCIAL INTERACTION FRAMEWORK}

One of the most significant attributes of mobile technologies, according to Kukulska-Hulme and Traxler (2005) is their ability to support situated learning. This is significant in the learning process because the student needs to be active in learning interaction in collaboration with the teacher and peers. Mobile learning is more strongly mediated by its context than the content of the study material (Sharples et al. 2005). In this paper an attempt is made to locate context within the social interaction framework. This perspective is based on the assumption that individual mental processes have their origin in social interaction (Vygotsky, 1930/1978). Social interaction is a critical component of people becoming involved in a community of practice which embodies certain beliefs and behaviours to be acquired (Lave \& Wenger, 1991). It is a negotiation of identities between individuals in a given context which influence the experiences, beliefs and values that shape and confirm learning practices (Lave \& Wenger, 1991). According to Vygotsky's (1930/1978) contextual view, humans are embedded in a social context and human behaviour cannot be understood independently of this matrix. He focused on the connections between people and the cultural context in which they act and interact in shared experiences.

The potential for using MXit for UNISA students is enormous considering that it is a more interactive platform for collaborative learning that enhances social interaction. This view is highly valued in the African culture where a student grows very dependent on a teacher and his or her peers for learning. Most UNISA students reported that they belonged to informal study groups even though this is neither encouraged nor discouraged by the university (Makoe, 2007). In so doing, "students can feel immediate identification with others in their group and so lose feelings of isolation and over anxiety" (Thorpe, 1995). It is in these study groups that students adopt a communal approach to learning by sharing responsibility for reading and explaining course material (Lentell \& O'Rourke, 2004).

The notion of helping each other is based on the South African traditional concept of 'ubuntu' meaning "humanity to others" which espouses collectivity and harmony. It focuses on people's relations to each other, that is, umuntu ngumuntu ngabantu 'I am what I am because of who we are all'. This philosophy describes the importance of group solidarity on issues that are pivotal to the survival of African communities. In this culture, meaning making is influenced by negotiations with family members, teachers and peers. Peers are the most influential group with whom people implicitly negotiate their understandings of their study materials. Therefore, MXit becomes a viable tool to provide students with an opportunity to motivate each other while learning. That way, students feel that they are in control of their activity of learning through collaborative engagement with others (Sharples, 2002). Mobile devices, according to Traxler (2007) support "learning that recognises the 
context and history of each individual learner and delivers learning to the student when and where they want it" (p.7).

\section{METHODOLOGY}

In trying to understand how people engage in social interaction in MXit, a pilot study was conducted with 23 UNISA students who belonged to five study groups with each ranging from three to seven members. These study groups were led by one female and four male students enrolled in different undergraduate courses at UNISA. The first initial meeting was held with four group leaders who were briefed about the objectives of the project and they were asked to invite their peers who may be interested in joining the study groups. The fifth group was formed a month after other groups had commenced. Group leaders invited their peers who were in their contact list. To participate in the MXit chatroom, one needs to be invited and the other party must accept. Users in the chatroom often use pseudo names and the phone numbers of their guests are kept anonymous. However, MultiMix allows an individual to invite multiple friends who do not necessarily have to be on each other's contact list.

As the momentum of the project grew, more members invited their peers. All participants were black students (12 females and 11 males) and their age group ranged from 19 to 28 years old. At least one of the study groups was able to attract distance education students from two other provinces to participate in the study. What each group leader did was to participate in the discussion and then download the discussion thread from his or her cellphone to the computer and then forward it to the researcher who collated data. Participants were more active contributors of information than passive sources of data.

This method was particularly useful in gathering data from a group of younger students because they were able to provide social contexts, in which their ideas were formed, as well as providing frameworks for understanding their world. Since MXit is mostly used exclusively by younger people, older people who participate are perceived as intruders into their space. In an African tradition, interaction between different age groups is based on respect for the elders. Age differences bind people together in specific social relationships where an older person carries a higher social status. Therefore, the culture of respect towards the teacher is often associated with the perception of an authoritative source of knowledge. Removing myself (as an elder, researcher and teacher) from the process of gathering data allowed students to communicate openly with one another. This was also beneficial because it allowed me to observe how students interacted with each other, the language they used and how they defined who belongs to the group. The purpose was to find out how participants 
used MXit to form study groups for the purpose of interacting, supporting and learning from each other.

The researcher's role was to translate from instant message language to standard English and analyse collated data. The number of discussion threads received ranged from three to 12 sessions from each study group over a period of four months. The data was then analysed by using Van Manen's (1990) basic steps which focus on the essential themes that characterize social interaction as a guiding framework. The discussion threads were initially grouped into discussions that were subject specific; support related; and those that dealt with general or current affairs. For the purposes of this paper only two discussion threads out of 36 were analysed to show how MXit was used to form study groups and facilitate social interaction amongst distance education students. The one discussion is about how participants were invited and the second deals with how one student helped the other with their assignments.

The extract below is one of the eight initial interactions that were sent to potential study group members.

T-liscious: Hey (Hello)

Bootie: $\quad W U$ (What's up)

Hvnt hed $4 r m$ u in long tym (Have not heard from you in a long time)

T-liscious: $\quad$ Yeah wanna ask u smtin - wana bcum prt of da study grup

(I want to ask you if you would be interested in joining our study group)

Bootie: Wat studi grup (What study group)

T-liscious: $\quad$ Studi grup in our unisa crse usn MXit

(study group in our unisa course using MXit)

Bootie: $\quad U$ meen chtn on MXit abt it (You mean chatting about the course on MXit)

T-liscious: $\quad$ Yeh

Bootie: $\quad$ Cnt me in bro (Count me in)

This interaction was selected as an example of how group leaders went about inviting participants. MXit users usually use pseudo names such as Bootie and T-liscious that enables them to hide their identity. Social networks such as MXit provide a familiar and comfortable context where people do not have to worry about dressing up, how they look and how others would react to their external appearance. "As individuals engage socially, 
they project aspects of their internal identity into a social identity for others to perceive" (Guvi, 2007).

The brief extract below is one of the 14 discussion threads that were subject-specific. It was sent by a group leader of the computer science study group.

Razor : $\quad$ dsignin tht knd of a wbsyt wud b reli chlengin'. it's nt only a wbsyt tht 1 hs 2 devlop bt shud b setup lyk a systm (Designing that kind of website would be really challenging. It is not only a website that one has to develop but should be set-up like a system.)

T.S : wht do $\cup$ by a systm?

(What do you mean by a system?)

Razor : $\quad 4$ startas $U$ sayin tht wht Ure syt 2 b dynmic $n$ usa frndly. beta codin wil $b$ required in tht instnt. Nw since $U$ wnt usas $2 b$ able 2 regstr on da syt $n$ b aloctd accnts, $u, I$ hv 2 Ink da pges 2 a dtbas in seva.

(For starters you are saying that you want your system to be dynamic and user friendly, better coding will be required in that instance. Now, since you want users to be able to register on the system and be allocated accounts, you'll have to link the pages to a database in a server.)

T.S : Ok

Razor : $\quad n$ tht constitute a systm (And that constitutes a system)

T.S : $\quad$ so hw do U suggst I go abt setin it up?

(So how do you suggest I go about setting it up?)

Razor : I tink U cud use difrnt prgms to devlop de whle systm. (I think you could use different programs to develop the whole system)

T.S : Ok. $n$ wht wil dey $b$

(Ok and what will they be)

Razor : $\quad U$ cn use 1 prgm 2 desgn de pages nd anada 4 desgnin de datbse. 4 eg u cud use html or javascript to ryt u're wsyt $n$ use languags sch as Delphi, oracle or even ms access 4 da base. 
(You can use one program to design the pages and another for designing the database. For example, you could use html or javascript to write your websystem and use languages such as Delphi, Oracle or even MS Access for the database)

T.S : so hw do I link da two?

(So how do you link the two)

Razor : $\quad U$ jst wryt a Ink on de page tht wil dyrct a tag eg (submit) 2 de base whr de info on de order or form page wil b stord.

(You just write a link on the page that will direct a tag for example (submit) to the database where the information on the order or form page will be stored.)

T.S : it sounds gud

Students who participated in this study had a need to get together, engage in joint activities and discussions, help each other and share information as illustrated in the extract. Like in other virtual communities, people who participated in these groups wanted to satisfy their needs for relationship, interest, transaction and fantasy (Hagel \& Armstrong, 1997).

\section{DISCUSSION AND CONCLUSION}

Through MXit, users claimed their space where they get together, speak their language, exchange ideas and belong to a community that is exclusively theirs. The language used gives them a sense of power over people who know very little about their world. For Vygotsky (1930/1978), tools, language, and other sign systems are important not simply as representational systems, but as resources in action. Initially children develop these tools to serve solely a social function as ways to communicate needs. Users of MXit have introduced a language that is only understood by users of their network. This was a natural development, according to Guvi (2007) "to create a distance from adults and other groups in seeking to fulfill their need to feel empowered, create identity and obtain a sense of belonging" (Guvi, 2007, p.14).

MXit can be designed for education "as networked tools that support, encourage individuals to learn together while retaining individual control over their time, space, presence, activity, identity and relationship" (Anderson, 2007). The socio-cultural theory has its roots on how the person is constructed in a social context; and how he or she forms relationships of desire and recognition (Packer \& Goicoechea, 2000). That is why Mxit tends to be very popular 
with young people. It affords them a space to be who they want to be. In this type of public or virtual space there are no social etiquettes, people can create fake identities, and there is no retribution or consequences to face up to (Guvi, 2007).

The highly interactive environment that this forum presents "enhances members' perception of social presence, co-presence and sense of place [as well as] facilitating the construction of reality for its members" (Porter, 2004). MXit has the potential to be used to support collaborative learning amongst distance learners. In distance education there is a strong correlation between care and learner motivation. Distance education providers will do well by developing guides and programmes aimed at empowering students to help each other through using social networks. Supporting self-directed study groups will build communities of practice which are formed by people who engage in a process of collective learning. The focus of mobile learning support should therefore be on assisting informal study groups to become self-sustaining.

\section{REFERENCES}

Anderson, T. (2007) Reducing loneliness of the distance learner using social software, a paper presented at the $12^{\text {th }}$ Cambridge International Conference on Open and Distance Learning, Retrieved February 4, 2008, from http://www2.open.ac.uk/r06/conference/TerryAndersonKeynoteCambridge2007.pdf,

Butgereit, L. (2007) Math on MXit: Using MXit as a medium for mathematics education, Retrieved April 3, 2008, from http://researchspace.csir.co.za/dspace/bitstream/10204/1614/1/butgereit 2007

Brindley, J.E., and Paul, R. (2004) The role of learner support in institutional transformation A case study in the making. In J. E. Brindley, C. Walti, and O. Zawacki-Richter (Eds.), Learner support in open, distance and online learning environments, Oldenburg: Bibliotheks- und Informationssystem der Universität Oldenburg: 39-50.

Guvi, K. (2007) Cataclysmic or enchanting: The impact of private spaces on broader social interaction amongst teenagers. Retrieved February 20, 2008, from http://www.tnsglobal.co.za/research-papers/pdf/SAMRA\%20paper\%20-\%20Kudzi\%20Guvi, 2007\%20-\%20May\%202007.pdf.

Hagel, J. and Armstrong, A. (1997) Net gain: Expanding markets through virtual communities. Boston, MA: Harvard Business School Press. 
Kreijns, K.Kirschner, P.A. and Jochems, W. (2003) Identifying the pitfalls for social interaction in computer supported collaborative learning environments: a review of the research, Computers in Human Behaviour, 13 (3), p.335-353.

Kukulska-Hulme, A. and Traxler, J. (2005) Mobile learning: A handbook for educators and trainers. London: Routledge.

Lave, J. and Wenger, E. (1991) Situated learning: Legitimate peripheral participation. New York: Cambridge University Press.

Lentell, H. and O' Rourke, J. (2004) Tutoring large numbers: an unmet challenge, International Review of Research in Open and Distance Learning, 5(1), Retrieved September 21, 2008, from www.irrodol.org/index.php/irrodol/article/viewArticle/171/253

Makoe, M.E. (2007)Students' experiences and conceptions of learning in a South African distance education context, Unpublished PhD thesis, Open University, Milton Keynes

MXit (2010) MXit Mobile Instant Messenger home page. Retrieved April 7, 2010, from http://www.mxitlifestyle.com/

Packer, M.J. and Goicoechea, J. (2000) Socio-cultural and constructivist theories of learning: Ontology, not just epistemology, Educational Psychologist, 35, 227-241.

Porter, C.E. (2004) A typology of virtual communities: A multi-disciplinary foundation for future research, Journal of Computer Mediated Communication, 10 (1) Retrieved March, 3, 2008, from http://jcmc.indiana.edu/vol10/issue1/porter.html

Prensky M. (2001) Digital natives, digital immigrants. On the Horizon, NCB, University Press.

Sharples, M. (2002) Disruptive devices: mobile technology for conversational learning, International Journal for Continuing Engineering Education and Life Long Learning, $12(5 / 6), 504-520$.

Sharples, M., Taylor, J. and Vavoula, G. (2005) Towards a theory of mobile learning Retrieved February, 20, 2008, from http://www.mlearn.org.za/CD/papers/Sharples20Theory\%20of\%20Mobile.pdf.

Thorpe, M. (1995) Bringing learner experience into distance education. In Sewart D (ed), One World, Many Voices: Quality in Open and Distance Learning : Selected Papers from the 17th World Conference of the International Council for Distance Education, Birmingham, United Kingdom, June 1995.

Traxler, J. (2007) Defining, discussing and evaluating mobile learning: The moving finger writes and having writ.... International Review of Research in Open and Distance 
Learning, 8(2). Retrieved March 23, 2009, from

http://www.irrodl.org/index.php/irrodl/article/view/346/875

UNISA (2009) Factsheet: Open Distance Learning, Pretoria, University of South Africa www.unisa.ac.za

Van Manen, M. (1990) Researching lived experience: Human Science for an Action Sensitive Pedagogy, Albany, N.Y, State University of New York Press

Vygotsky, L.S. (1930/1978) Mind in Society: The development of higher psychological processes. Cambridge, M.A. Harvard University Press.

World FactBook (2010) Country Comparison: Telephones - Mobile Cellular, Retrieved April 7, 2010, from https://www.cia.gov/library/publications/the-world factbook/rankorder/2151rank.html 